\title{
INFLATION, INFLATION UNCERTAINTY, AND A COMMON EUROPEAN MONETARY POLICY
}

\author{
by Stilianos Fountas, Alexandra I oannidis ${ }^{\mathrm{y}}$ \\ and Menelaos K aranasos ${ }^{z}$ \\ J une 2003
}

\begin{abstract}
A bstract
The relationship between infation and in $\ddagger$ ation uncertainty is investigated in six European Union countries for the period 1960 to 1999. EGARCH models are used to generate a measure of in $\ddagger$ ation uncertainty and then Granger methods are employed to test for causal ity between average in $¥$ ation and in ation uncertainty. In all the European countries, except Germany, infation signi..cantly raises infation uncertainty as predicted by Friedman. However, in all countries except the UK, in ation uncertainty does not cause negative output exects, implying that a common European monetary policy applied by the ECB might not lead to asymmetric real exects via the in $¥$ ation uncertainty channel. Less robust evidence is found regarding the direction of the impact of a change in infation uncertainty on infation. In Germany and the N etherlands, increased in $\neq$ ation uncertainty lowers in $\neq$ ation, while in Italy, Spain, and to a lesser extent France, increased inłation uncertainty raises in $\ddagger$ ation. Theseresults are generally consistent with the existing rankings of $C$ entral Bank Independence.
\end{abstract}

Keywords: EMU, Exponential GARCH, In‡ation, In‡ation Uncertainty.

J EL Classi..cation: C22, C32, E31, E58.

We are indebted to two anonymous referees for very useful comments and suggestions.

We also thank Alex Cukierman, Soren J ohansen, Marika Karanassou, Paul Mizen, Iannis M ourmou ras and participants in the 5th A nnual C onferenceon Macroeconomic A nalysis and International Finance (Crete, 2001), the conference on EM U Institutions and Macroeconomic Policies (M ilan, 2001) and the I rish Economic A ssociation annual conference (Mullingar, 2002) for helpful comments and suggestions. The usual disclaimer applies.

\footnotetext{
${ }^{\text {DD }}$ epartment of E conomics, U niversity of M acedonia, 156 Egnatia St., T hessaloniki 540 06, G REECE; e-mail: sfountas@uom.gr

'Department of Economics, University of York, Heslington, York Y010 5DD, UK; e-mail: ai107@york.ac.uk.

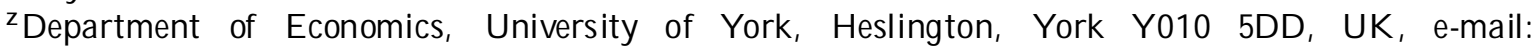
mk16@york.ac.uk.
} 


\section{INTRODUCTION}

The importance of infation uncertainty as a distinct channel in explaining the real exects of infation has recently been given considerable empirical support (Grier and Tullock, 1989, Grier and Perry, 2000, J udson and Orphanides, 2000). This channel was ..rst highlighted in Friedman's (1977) N obel lecture. Friedman supplied an informal argument that an increase in the average in $\ddagger$ ation rate would lead to more in $\ddagger$ ation uncertainty, thus creating distortions in the workings of the price mechanism in allocating resources et ciently. Subsequent theoretical research focused on the opposite type of causation, which runs from in $\ddagger$ ation uncertainty to in $\ddagger$ ation. For example, Cukierman and M eltzer (1986) employ the Barro-Gordon set up and show that an increase in uncertainty about money growth and in $\ddagger$ ation will increase the optimal average in $\ddagger$ ation rate because it provides an incentive to the policymaker to create an infation surprise in order to stimulate output growth. Holland (1995) argues that more in $\ddagger$ ation uncertainty can lead to a lower average inłation rate if the Central Bank tries to minimise the welfare losses arising from more in $\ddagger$ ation uncertainty. In addition, the evidence on the direction of the exect of in ation uncertainty on infation can be compared with the existing measures of Central Bank Independence (Grier and Perry, 1998). These authors do ..nd that the most independent Central Banks are in countries where in $\ddagger$ ation declines as in $\ddagger$ ation uncertainty rises, thus contradicting the Cukierman-M eltzer hypothesis.

The issue of the relationship between inłation, in $\ddagger$ ation uncertainty, and output growth acquires great importance for the member countries of the Euro zone. First, evidence that higher inłation causes more in $\ddagger$ ation uncertainty and, therefore, possible negative output exects would strengthen the case for the choice of price stability by the E uropean Central B ank (ECB) as one of the primary objectives of monetary policy. Second, if the exects of in $\ddagger$ ation on output that take place via changes in in $\neq$ ation uncertainty dixer across the Euro zone, it is possible that a common monetary policy that results in similar in $\neq$ ation rates across countries will have asymmetric real exects. In other words, a reduction in infation arising from a contractionary monetary policy applied by the ECB could reduce output in some countries but increase output in others, depending on the combination of two exects: (a) The Friedman hypothesis, i.e., the exect of in $\neq$ ation on in $\ddagger$ ation uncertainty and (b) the exect of in $\ddagger$ ation uncertainty on output growth. Therefore, lack of uniform evidence supporting the exect of in $\ddagger$ ation on output via the in $\ddagger$ ation uncertainty channel across the E uro-zone countries would have important policy implications as it would make a common monetary policy a less exective stabilization policy tool in dealing with national disparities.

A utoregressive Conditional Heteroskedasticity (ARCH) and Generalized ARCH (GARCH) techniques represent a commonly-used approach to proxy uncertainty using the conditional variance of unpredictable shocks to the infation rate ${ }^{1}$. These techniques have recently been employed by Grier and Perry (1998) to investigate the direction of causality in the inłation-inłation uncertainty relationship for the $\mathrm{F}^{2}$. Similarly, Grier and Perry

\footnotetext{
${ }^{1} \mathrm{~A}$ Iternative measures of uncertainty include survey-based forecasts and a moving standard deviation of inf ation.

${ }^{2}$ We dixer from this study in several respects: the GARCH model employed, the sample period, the data frequency, the country group, and the consideration of output growth and its relationship with
} 
(2000) aim to examine the in ation-output uncertainty nexus in the US. The empirical evidence to date on the Friedman and the Cukierman-M eltzer hypotheses provided by Grier and Perry (1998) and a few other recent studies summarised below is rather mixed. Grier and Perry $(1998)^{3}$ use a GARCH model to estimate in $\ddagger$ ation uncertainty and run Granger causality tests. We employ an exponential GARCH (EGARCH) model for two reasons: First, we ..nd evidence for asymmetries in the inłation uncertainty-inłation relationship and, second, we follow Brunner and Hess (1993) in testing Friedman's hypothesis.

O ur paper contributes to the empirical relationship between inłation and inłation uncertainty in several ways: First, we use an EGARCH model instead of a $\mathrm{GARCH}$ model, as discussed above. Second, we examine the relationship between in ation and in ation uncertainty for several EU countries in order to examine whether a case could be made against a common monetary policy, along the lines discussed above. Third, we examine whether in $\neq$ ation is costly, a much-debated issue in monetary economics. Our approach allows us to distinguish between the direct costs of infation, and those that arise via the infation uncertainty channel, as predicted by Friedman (1977). The rest of the paper is structured as follows: In section 2 our theoretical econometric model is presented. In section 3 we summarise our empirical results. In section 4 we interpret these results and relate them to the predictions of economic theory and other recent empirical studies. Finally, section 5 concludes.

\section{THE EGARCH MODEL}

\subsection{THE AR(p)-EGARCH $(1,1)$ PROCESS}

One of the principal empirical tools used to model infation uncertainty has been the ARCH class of models. Following Engle's (1982) pathbreaking idea, several formulations of conditionally heteroscedastic models (e.g. GARCH, Fractional Integrated GARCH, Switching GARCH, Component GARCH) have been introduced in the literature, forming an immense ARCH family. However, as Brunner and Hess (1993, p. 187) argue, "The GARCH model places a symmetric restriction on the conditional variance. Since the variance is a function of squared residuals, agents become more uncertain about future infation whether infation unexpectedly falls or unexpectedly rises. The essence of Friedman's hypothesis is inconsistent with such a symmetry restriction, since new information suggesting that in ation is lower should reduce, rather than raise, uncertainty about future in ation".

Many of the proposed GARCH models include a term that can capture correlation between the in $\ddagger$ ation rate and inłation uncertainty. Models with this feature are often termed asymmetric or leverage vol at ility models. One of the earl iest asymmetric GARCH models is the EGARCH model of Nelson (1991). In contrast to the conventional GARCH speci...cation which requires nonnegative coec cients, the EGARCH model, by modeling

\footnotetext{
inłation uncertainty.

${ }^{3}$ The authors estimate both asymmetric and symmetric GARCH models. However, they cannot reject the null hypothesis of symmetry. They, therefore, proceed to perform the Granger-causality tests using the estimated conditional variance from the GARCH model of each country.
} 
the logarithm of the conditional variance, does not impose the nonnegativity constraints on the parameter space. Of the many dixerent functional forms, the EGARCH model has become perhaps the most common. In particular, various cases of the EGARCH model have been applied by many researchers. For example, Brunner and Hess (1993), using EGARCH models, ..nd that estimates of the conditional variance of U.S. in ation are very similar to those obtained using state-dependent models.

We model the conditional mean of infation as

$$
\mathbb{C}(L) y_{t}=\phi+\varepsilon_{t},
$$

with

$$
\mathcal{O}(L), Y_{l=1}^{Y_{p}}\left(1 \mathbf{i} \phi_{l} L\right),
$$

where $y_{t}$ denotes the rate of infation. Equation (1) is simply an $A R(p)$ process.

In addition, we model the time-varying residual variance as an $\operatorname{EGARCH}(1,1)$ process. This can be written as

$$
\begin{aligned}
\varepsilon_{t} & =e_{t} h_{t}^{\frac{1}{2}}, \\
(1 \mathrm{i} \beta L) \ln \left(h_{t}\right) & =\omega+d \boldsymbol{\rho} \frac{\varepsilon_{t \mathrm{i} 1}}{\overline{h_{t \mathrm{i}} 1}}+c \overline{-} \frac{\overline{\varepsilon_{t \mathrm{i} 1}}}{\overline{h_{t \mathrm{i} 1}}}=
\end{aligned}
$$

where $e_{t} \mathbf{g}$ is a sequence of independent, normally distributed random variables with mean zero and variance 1 . In the empirical work reported below, we estimate $A R(p)$ EGARCH $(1,1)$ models for in ation and then use the conditional variance $h_{t}$ as a measure of inłation uncertainty.

\section{EMPIRICAL ANALYSIS}

\subsection{METHODOLOGICAL ISSUES}

The relationship between in $\ddagger$ ation and in ation uncertainty could be estimated in a simultaneous approach as in a GARCH-in-mean (GARCH-M) model that includes a function of the lagged infation rate in the conditional variance equation or a two-step approach where an estimate of the conditional variance is ..rst obtained from a GA RCH-type model and then causality tests are run to test for bidirectional exects. Examples of the former approach include Brunner and Hess (1993), Grier and Perry (1998), B aillie et al (1996) and Fountas et al (2000) ${ }^{4}$. The latter approach was followed in Grier and Perry (1998).

\footnotetext{
${ }^{4}$ Grier and Perry (1998) use a Component GARCH-M model of US inłation that includes lagged infation in the conditional variance, whereas Brunner and Hess (1993) use a state-dependent model
} 
The simultaneous approach suxers from the disadvantage that it does not allow the testing of a lagged exect of inłation uncertainty on inłation, which would be expected in a study that employs monthly or quarterly data. A s G rier and Perry (1998) mention, the impact of a change in inłation uncertainty on average in $¥$ ation, via a change in the stabilization policy of the monetary authority, takes time to materialize and cannot be fairly tested in a model that restricts the exect to being contemporaneous.

\subsection{The EMPIRICAL EVIDENCE TO DATE}

The inłation-in‡ation uncertainty relationship has been analysed extensively in the empirical literature. Holland (1993) and Davis and Kanago (2000) survey this literature. In ation uncertainty is measured either using survey-based forecasts of in ation or the GARCH approach. In the recent literature that employs the GARCH approach, the U.S. evidence in favour of the Friedman hypothesis is mixed. B runner and Hess (1993), Grier and Perry $(1998,2000)$ and Fountas et al (2000) ..nd evidence in favour, whereas Baillie et al (1996) ..nd evidence against it. The US evidence on the Cukierman-M eltzer hypothesis is rather negative. Only Fountas et al (2000) ..nd evidence in favour of the hypothesis. T here are a limited number of studies using international data that employ the GARCH approach. They are Baillie et al (1996) and Grier and Perry (1998). Grier and Perry (1998) ..nd evidence supporting the Friedman hypothesis in the rest of the G7 countries but B aillie et al (1996) ...nd mixed evidence. Grier and Perry (1998) ..nd evidence supporting the Cukierman-M eltzer hypothesis in J apan and France and Baillie et al (1996) in the UK and three high-inłation economies, Argentina, Brazil and I srael.

This study aims to ...l the gaps arising from the methodological shortcomings of the previous studies and thelack of interest in the E uropean case, where the results would have interesting implications for the successful implementation of common E uropean monetary policy.

\subsection{UK RESULTS}

\subsubsection{DESCRIPTION OF THE UK DATA AND ESTIMATION RESULTS}

We ..rst test for the relationship between in ation and infation uncertainty using UK data. Even though the UK is not presently a member of the E uro zone, it is likely that it will participate in the European monetary union (EMU) in the future. In our empirical application we use non-seasonally adjusted time series data on Consumer Price Index obtained from the OECD Main Economic Indicators Database. Our sample includes quarterly data from 1960:Q1 through 1999:Q2. Figure 1 plots the infation rate $\left(\pi_{t}\right)$ series constructed as the ..rst dixerence of the log of CPI. To establish that the infation data series is stationary we use both the A ugmented Dickey-Fuller (ADF) and Phillips-Perron (PP) tests presented in Table 1(a) below. U sing the second lagged dixerence terms in

where the standard deviation of in $\neq$ ation is included in the mean equation and the lagged value of the squared deviation of in ation from a parameter is included in the variance equation. Baillie et al (1996) model in ation as a fractionally-integrated process and include lagged in $\neq$ ation in the conditional variance equation and the standard deviation in the mean equation. Fountas et al (2000) use a GARCH-M model that includes the lagged inłation rate in the variance equation. 
the ADF test and setting the truncation lag at four in the PP test, we ..nd that both tests reject the null hypothesis of a unit root at 0.01 signi..cance level. Hence, we have evidence in this sample that the UK infation rate is stationary. We choose an $A R(6)$ plus 2 seasonal dummy variables ${ }^{5}$ model for the mean in ation rate and an $\operatorname{EGARCH}(1,1)$ model for the variance equation, according to the minimum A kaike Information Criterion (AIC) and Schwarz criterion (SC).

Table 1(b) presents the estimates of an AR(6)-EGARCH $(1,1)$ model for the UK infation rate with two seasonal dummies. The model was estimated under quasi-maximum likelihood estimation using the consistent variance-covariance estimator of Bollerslev and Wooldridge (1992). Residual diagnostics for this model are also reported in Table 1(b), and include Ljung-B ox (Q) tests for residual correlation, and Ljung-B ox diagnostics for serial dependence in the squared residuals. As reported, the Ljung-B ox tests for serial correlation in the levels and squares of the standardized residuals do not reject the hypothesis of no autocorrelation. Thus, the Ljung-B ox tests indicate that the estimated model ..ts the data very well. The persistence of volatility implied by the EGARCH equation is measured by the size of $\beta$, which is highly signi...cant. A symmetry in in $\neq$ ation uncertainty is conveniently quanti..ed by examining the sign of $d$. In the present case, the positive and signi..cant value of the coec cient implies that periods of positive in ation shocks are accompanied by high inłation uncertainty and periods of negative in‡ation shocks are accompanied by lower uncertainty about infation. In summary, the $A R(6)-E G A R C H(1,1)$ model seems to ..t both the mean and variance of the UK infation rate quite well.

\subsubsection{GRANGER-CAUSALITY TESTS}

Next we employ Granger methods to test for bidirectional causality between inłation and in ation uncertainty. In particular, we test the null hypotheses that in $\ddagger$ ation does not Granger-cause in $\neq$ ation uncertainty, and that in ation uncertainty does not Grangercause infation using two, four, six, and eight lags ${ }^{6}$. The $F$ statistics are reported in Table 2. These statistics have been obtained following correction for serial correlation and/or heteroskedasticity in the unrestricted regression in each case. The ..rst null hypothesis is rejected at 0.01 level for all lags, while the second is also rejected at 0.10 or better. The sum of the coel cients on lagged uncertainty in the infation equation (at lags 2 and 6) and on lagged infation in the in ation uncertainty equation are positive. We thus provide strong empirical con..rmation of Friedman's hypothesis. We al so ..nd some evidence that increased in ation uncertainty increases in $\ddagger$ ation, con..rming the theoretical predictions made by Cukierman and Meltzer (1986).

Inłation uncertainty has real exects only if it leads to output losses. To test for such exects we have used the index of industrial production to construct the growth rate of output. Our Granger-causality results in Table 2 (fourth column) indicate that higher in $\ddagger$ ation uncertainty causes a negative output growth exect, thus supporting the argument

\footnotetext{
${ }^{5}$ The seasonal dummy variables are included to seasonally adjust the in $\ddagger$ ation series. We ..nd that 2 of these dummies are jointly statistically signi...cant.

${ }^{6}$ It is possible to test for the relationship betwen infation and its uncertainty simultaneously, as argued in Appendix A.
} 
that higher infation uncertainty is part of the welfare costs of inłation ${ }^{7}$. Finally, in the last column of Table 2, we report the F statistics on the causal exect of in $\neq$ ation uncertainty on output growth, where the regression includes in addition lagged in ation rates. The rationale for this choice is to control for possible exects of in $\neq$ ation uncertainty on output that take place via changes in in $\neq$ ation ${ }^{8}$. The reported results indicate that in $\ddagger$ ation uncertainty still axects output negatively, even though the exect is perhaps somewhat weaker (i.e., it applies for two and four lags only).

\subsubsection{PREDICTABILITY OF HIGHER LEVELS OF UK INFLATION}

Several researchers, such as Engle (1983) and Cosimano and J ansen (1988), have failed to ..nd strong evi dence that higher rates of in $\neq$ ation are less predictable. U sing the E GARCH model, we compare our results with theirs. The inłation and inłation uncertainty series for the $A R(6)$-EGARCH $(1,1)$ model are shown in Figure 2, which plots the in $\neq$ ation rate and its corresponding conditional standard deviation in dual scale.

In contrast to the conclusion of the above-mentioned studies, Figure 2 provides evidence that higher levels of in $\ddagger$ ation are less predictable. According to our estimates, the conditional standard deviation average (annual rate) in the low-infation 1960s is about 2.4\%. In the high-infation 1970s, the conditional standard deviation average (annual rate) is about $4.3 \%$. F inally, in the low-infation environment of the 1990 s, the average of the conditional standard deviation is only $2.4 \%$. B runner and Hess (1993) argue that it is the relaxation of the symmetry restriction in conditional volatility models which enables them to ...nd that higher levels of in $\ddagger$ ation are less predictable. We reach the same conclusion by using an EGARCH model. To compare our results to theirs we al so use an asymmetric GARCH process. The AIC and SC were -6.979647 and -6.759845 respectively, much worse than those of the EGARCH model. The est imates of the conditional standard deviation were quite unsatisfactory as well. F igure 3 shows that the volatility of in $\neq$ ation for the GARCH model is unreasonably high during the relatively low and stable in $\neq$ ation years of the late 1980s and 1990s.

\subsection{EVIDENCE FOR THE EURO-ZONE COUNTRIES}

\subsubsection{DESCRIPTION OF THE DATA AND ESTIMATION RESULTS}

We apply the above empirical approach to ..ve European countries (France, Germany, Italy, the N etherlands, and Spain) that are presently members of the Euro zone. Our group of countries includes the largest four EMU countries. We use quarterly non-seasonally adjusted time series on CPI obtained from the OECD main economic indicators database from 1960:Q 1 to 1999:Q39 ${ }^{9}$. To adjust the time series for seasonality, we use 3 seasonal dummy variables in each country, provided they are jointly signi..cant ${ }^{10}$.

\footnotetext{
${ }^{7}$ This result is identical if we use GDP to measure real output.

${ }^{8} \mathrm{We}$ are grat eful to an anonymous referee for this point.

${ }^{9}$ The time series for France ends in 1999:Q 2, for Germany in 1999:Q 2, for Italy in 1999:Q 3, for the Netherlands in 1999:Q2, and for Spain in 1999:Q2.

${ }^{10}$ The seasonal dummy variables are jointly signi..cant in all the examined countries except for the Nether lands and Spain.
} 
Table 3 presents A DF and PP tests of the unit root hypothesis for each country. The PP tests reject the null hypothesis of a unit root for all six countries at $0.01(0.05$ for France) signi..cance level. The ADF tests for France, Germany, and Italy fail to reject the null hypothesis of a unit root, but we will consider their infation series stationary in our analysis, taking into consideration the Phillips-P erron results.

The best ..tted model is chosen according to the minimum values of the AIC and SC. We choose an EGARCH $(1,1)$ speci...cation for the conditional variance and an $A R(3)$ model for France, an AR(7) for Germany, an $A R(4)$ for Italy, and an $A R(8)$ for the Netherlands and Spain. Table 4 shows the estimated results for each country for the models speci..ed above. In all countries, except Germany, the estimated coet cient $d$ is statistically signi..cant and positive, indicating evidence of asymmetry in the conditional variance. This implies that negative and positive shocks to the in $\ddagger$ ation process have a dixerent impact on inłation uncertainty. More speci..cally, positive (negative) inłation surprises lead to more (less) inłation uncertainty. For Germany, the estimated coef..cient of asymmetry is negative, implying that a positive infation shock leads to less uncertainty about infation. This ..nding can be attributed to the strong commitment of the German monetary authority towards anti-inłationary policies. We also perform the same speci..cation tests for the adequacy of the models as we did for the UK above. For all the estimated models, residuals diagnostics (not reported) yield no evidence of mis-speci..cation.

\subsubsection{GRANGER-CAUSALITY TESTS}

Table 5 reports the Granger-causality test results for the above ...ve countries. The null hypothesis that in ation does not Granger-cause in ation uncertainty is rejected for all the examined countries at the 0.05 level and for each lag length, except G ermany. These results are similar to those of the UK, supporting the Friedman hypothesis. The null hypothesis that infation uncertainty does not Granger-cause in $¥$ ation is rejected in all countries. However, only in the case of Italy, France ( 2 lags) and Spain (6 and 8 lags) is the exect positive, supporting the Cukierman - M eltzer hypothesis. For Germany and the Netherlands, where the exect is negative, we ..nd evidence in favour of Holland's (1995) stabilisation hypothesis discussed below.

$F$ inally, the fourth column of Table 5 indicates that infation uncertainty does not Granger cause output growth in all countries, except perhaps Italy, where we ..nd a signi...cant and negative impact on real output growth at the $10 \%$ level and the Netherlands and Spain, where the exect is positive Somewhat similar results apply in the last column of Table 5, which adds the in ation rate in the right-hand side of the regression. The only dixerences are the insigni...cance of infation uncertainty in Italy and the slight evidence for a positive impact in France. These results are discussed further below ${ }^{11}$.

\footnotetext{
${ }^{11}$ The choice of the industrial production index in measuring real out put is dictated by the unavailability of quarterly national acccounts (and hence GDP) for the full sample period for several countries in our sample.
} 


\subsubsection{PREDICTABILITY OF INFLATION}

As in the case of UK inłation, there is evidence that higher rates of inłation are less predictable for each of the other European countries. This conclusion is derived from an examination of the plots (not reported) of the in $\ddagger$ ation rate and its corresponding conditional standard deviation for each country. This result is in agreement with the conclusion of Brunner and Hess (1993) for the US. According to our estimated model for France, the average of the conditional standard deviation (annual rate) in the high-in ation 1970s is $2 \%$ and in the low-infation environment of the 1990 s only $0.9 \%$. Similarly, according to our estimated model for Spain, the average value of the conditional standard deviation (annual rate) in the 1970 s is $4 \%$ whereas in the stable infationary environment of the 1990s the average ..gure is $1.6 \%$. Similar results apply for the rest of the countries in our sample.

\subsection{ROBUST NESS}

Our sample period 1960-99 includes various exchange rate and monetary policy regimes. For example, the UK operated under a managed ¥oat regime, following the collapse of the B retton Woods system, for most of our sample, except for the brief period of ERM participation. In addition, from 1979 to 1990, T hatcher's government emphasised a strong anti-inłation objective. Hence, we repeat the above analysis for the UK for two periods: 1973-99 (the managed $\ddagger$ oat regime) and 1979-90 (the Thatcher years). The results are presented in Table 6. Overall, these results are in broad agreement with those reported in Table 2. It is interesting to note that during the T hatcher years infation uncertainty had no impact on output growth, a result that is very robust to the presence or absence of lagged infation in the regression equation. Moreover, there is some evidence, in both periods under consideration, that inłation uncertainty lowers infation, in agreement with the stabilisation hypothesis.

For the rest of our sample, countries that were ERM members for most of our original sample period 1960-99, we repeat the above analysis for the period 1983-9912. The choice of this period is based on the widely accepted notion that the ERM entered a calmer phase in 1983 following the turbulent early years (G ros and T hygesen, 1992). Following the estimation of GARCH models for each country (results not reported), we perform Granger-causality tests as previously and report the results in Table 7 . These results support those reported for the full sample period (see Table 5) in many respects. First, we ..nd strong support for the Friedman hypothesis regarding the positive impact of infation on infation uncertainty in most countries (see column 2). Second, as was the case in the analysis of the full period, we ..nd that inłation uncertainty does not seem to lead to lower output, with a single exception (last two columns of Table 7). Finally, signi..cant dixerence obtains between the full sample and the post-1983 period on the signi..cance of the causal exect of inłation uncertainty on inłation. We ..nd (column 3) that in most countries, there is no causal exect. This result squares with the loss of

\footnotetext{
${ }^{12}$ For all 6 countries, we have re-estimated the GARCH model using the new sample periods and obtained new values for the conditional variances. These values have then been used in performing the Granger-causality tests.
} 
monetary policy independence in the ERM period, as monetary policy was constrained by the exchange-rate peg objective.

\section{DISCUSSION}

Our full sample period includes considerable in $\ddagger$ ation diversity both across countries and across time. The high-in $\neq a$ tion 1970s was followed by the low-in $\neq$ ation 1980s and 1990s. This was the case for two reasons: First, the global reduction in infationary pressures. Second, some European countries, France, Italy, and Spain in our sample, joined the European M onetary System (EM S) in 1979 in order to borrow Germany's anti-inłation reputation. This is less so for the N etherlands, which has traditionally aligned its monetary policy stance to Germany's. The reduction in inłation for France, Italy, and Spain was more prevalent during the last stage of the EMS, starting in 1987. During most of the 1990s, infation remained low and relatively stable. The signi..cant variability in the level of infation and the uncertainty about it during our sample period provides the testing ground to examine the bidirectional relationship between in $\ddagger$ ation and in $\ddagger$ ation uncertainty.

We discuss ..rst the Granger-causality results on the exect of infation on in ation uncertainty. Our results indicate strong evidence in support of the Friedman hypothesis for all countries, except G ermany ${ }^{13}$. The lack of evidence for Germany is not surprising, as it is consistent with Ball's (1992) theory, which formalised Friedman's prediction ${ }^{14}$. Using Ball's (1992) argument, an increase in German inłation would not lead to more in $\ddagger$ ation uncertainty as the Bundesbank had a strong anti-inłation reputation, and, therefore, was willing to bear the costs of disinfation. Our result on the Friedman hyp othesis for France, Italy, and the UK is consistent with the Grier and Perry (1998) study of the G 7. However, in contrast to our study, Grier and Perry (1998), using a dixerent methodology (GARCH model), sample size (1948-93), and data frequency (monthly, as opposed to quarterly) ..nd support for Friedman's hypothesis for G ermany. Our ..nding of a non causal ex ect of infation on infation uncertainty for this country indicates that infation uncertainty in Germany is not caused by rising inłation rates.

R egarding the causality from in $\ddagger$ ation uncertainty to output growth, our Grangercausality tests indicate that only in the UK does infation uncertainty have a negative exect on output growth (when the full period is used). In the EMU countries during the more relevant 1983-1999 period such an exect does not apply. This is according to the last column of Table 7 which allows us to separate the exects of infation uncertainty on output. Hence, we conclude that the welfare costs of infation do not seem to be signi..cant, with the exception of the UK ${ }^{15}$. This ..nding has important implications for the ECB's policymaking strategy. In particular, it supports those claiming that the objective

\footnotetext{
${ }^{13} \mathrm{No}$ evidence in favour of the Friedman hypothesis applies for the Netherlands and Spain when the 1983-99 period is used.

${ }^{14}$ Ball (1992) uses an asymmetric information game where two policymakers with dixerent preferences towards in $\ddagger$ ation alternate stochastically in o $c$ ce. T herefore, a higher curr ent in $\ddagger$ ation rate raises in $\ddagger$ ation uncertainty as it is not known which policymaker will be in o\& ce in the next period.

${ }^{15}$ For the UK, the welfare cost of in $\neq$ ation was contained by the adoption of in $\neq$ ation targeting in 1992 , following the country's brief participation in the EMS.
} 
of price stability has been overemphasised by the ECB. The second implication of these output growth Granger-causality results concerns the application of a common monetary policy by the ECB following the launch of the Euro zone in 1999. As we saw earlier, in ation uncertainty does not seem to cause negative real exects across all countries in our sample, except in the UK. Hence, a common European monetary policy would have relatively symmetrical real exects (=zero), which work through the infation uncertainty channel, across the EMU countries ${ }^{16}$.

O ur evidence on the Cukierman-M eltzer hypothesis is rather mixed. For Germany and the Netherlands, we ..nd evidence against this hypothesis. This evidence partially favours the "stabilization hypothesis" put forward by Holland (1995). He claims that for countries where infation leads to inłation uncertainty and real costs, we would expect the $C$ entral Bank to stabilize inłation, hence a negative exect of in ation uncertainty on infation. Our evidence is in part ${ }^{17}$ consistent with this argument for Germany and the N etherlands. In contrast, for I taly, France (2 lags) and Spain (not robust across the various lags considered) we ...nd evidence in favour of the Cukierman-M el tzer hypothesis. Hence, these countries would be expected to gain signi..cantly from EM U as the surrender of their monetary policy to the ECB would eliminate the policymakers' incentive to create in ation surprises. Finally, our evidence for the UK is rather mixed. At 2 and 6 lags, we ...nd evidence supporting the C ukierman-M eltzer hypothesis and at 4 and 8 lags evidence against the hypothesi s. Our evidence for France ( $\operatorname{lag} 2)$ and the UK ( 2 and 6 lags) squares with the ..ndings of Grier and Perry (1998) and Baillie et al (1996), respectively.

$M$ ore independent Central Banks would have stronger anti-infation preferences than the government and hencelead to a lower optimal inłation rate (Rogox, 1985). Moreover, if in ation uncertainty is costly, i.e., it implies real output exects, and inłation can axect in $\ddagger$ ation uncertainty (the Friedman hypothesis), an independent Central Bank will have a greater incentive (and freedom) to reduce in ation in response to more uncertainty. This is because in doing so (and hence keeping in $\ddagger$ ation uncertainty lower), the Central Bank can attain both lower in ation and higher output, i.e., a higher welfare level. The predictions of this analysis are borne out by the empi rical evidence. A lesina and Summers (1993) show that more independent Central Banks are indeed associated with both lower inłation and in ation uncertainty.

O ur results for the impact of inłation uncertainty on inłation are generally consistent with the existing literature on the rankings of Central Bank Independence (see A lesina and Summers, 1993). Countries like France, Italy and Spain have less independent Central Banks than G ermany and the Netherlands, at least using the measures of Central Bank Independence that refer to the pre-1990 period, which is more in line with our sample period. Hence, we would expect that less independent $C$ entral B anks would be more likely to cause inłation surprises in response to higher inłation uncertainty, a result consistent

\footnotetext{
${ }^{16}$ For the Netherlands, Spain, and possibly France, we ..nd evidence that in $\ddagger$ ation uncertainty raises output growth, in particular when the full sample period 1960-99 is used. This, seemingly, surprising result may arise under the assumption of risk averse agents and a precautionary motive for savings, as Dotsey and Sarte (2000) have shown in their theoretical model. According to their argument, when infation uncertainty rises, savings increase and this boosts investment and growth.

${ }^{17}$ Our partial support arises from a lack of evidence for a negative impact of in $¥$ ation uncertainty on output growth for these two countries and a lack of evidence for the Friedman hypothesis for G ermany.
} 
with the Cukierman-Meltzer hypothesis. Our empirical analysis generally supports this prediction. Our conclusion on France and Germany also agrees with Grier and Perry (1998).

\section{CONCLUSIONS}

The relationship between infation and infation uncertainty has been investigated in six European Union countries for the period 1960 to 1999. EGARCH models were used to generate a measure of in $\neq$ ation uncertainty and then Granger methods were employed to test for causality between average in $\ddagger$ ation and in $\ddagger$ ation uncertainty. In all the European countries of our sample, except Germany, inłation signi ..cantly rai ses inłation uncertainty, as predicted by Friedman. However, in all countries, except the UK, in $\neq$ ation uncertainty does not cause negative output exects, implying that a common European monetary policy applied by the ECB might not lead to asymmetric real exects via the in $\neq$ ation uncertainty channel.

Less robust evidence is found regarding the direction of the impact of a change in in $\ddagger$ ation uncertainty on in $\ddagger$ ation. In G ermany and the Netherlands, increased in $\ddagger$ ation uncertainty lowers infation, while in Italy, Spain, and to a lesser extent France, increased inłation uncertainty raises inłation. These results are generally consistent with the existing rankings of $C$ entral Bank Independence.

The reported dixerences in the results between this study and related studies, such as Grier and Perry (1998), can be attributed to the dixerent methodologies, sample periods, and data frequency. These dixerences highlight the need for further empirical work in search of more robust evidence on the relationship between in $\ddagger$ ation, in $\ddagger$ ation uncertainty and output growth. This work will provide an additional testing ground for the empirical relevance of economic theories and at the same time will be rather informative for the authorities in charge of monetary policymaking.

\section{REFERENCES}

A lesina, A. and Summers, L. (1993). Central Bank Independence and Macroeconomic Performance, J ournal of M oney, Credit, and Banking, Vol 25, pp. 151-162.

Baillie, R., Chung, C-F. and T ieslau, M . (1996). Analyzing Inłation by the Fractionally Integrated ARFIMA-GARCH Model, J ournal of A pplied Econometrics, Vol 11, pp. 23-40.

Ball, L. (1992). W hy does High Inłation Raise Inłation Uncertainty?, J ournal of M onetary Economics, Vol 29, pp. 371-388.

Bollerslev, T. and Wooldridge, J . (1992). Quasi Maximum Likelihood Estimation and Inference in Dynamic Models with Time Varying Covariances, Econometric R eviews, Vol 11, pp. 143-172.

Brunner, A. and Hess, G. (1993). A re Higher Levels of Inłation Less Predictable? A State-Dependent Conditional Heteroskedasticity Approach, J ournal of Business \& Economic Statistics, Vol 11, pp. 187-197. 
C osimano, T . and J ansen, D. (1988). Estimates of the Variance of US In ation Based upon the ARCH Model, J ournal of M oney, Credit, and Banking, Vol 20, pp. 409421.

Cukierman, A. and Meltzer, A. (1986). A Theory of A mbiguity, Credibility, and Infation Under Discretion and Asymmetric Information, Econometrica, Vol 54, pp. 1099-1128.

Davis, G. and Kanago, B. (2000). The Level and Uncertainty of Inłation: Results from OECD Forecasts, Economic Inquiry, $\mathrm{V}$ ol 38, pp. 58-72.

Dotsey, M. and Sarte, P. (2000). Infation Uncertainty and Growth in a Cash-inAdvance Economy, J ournal of M onetary Economics, Vol 45, pp. 631-655.

Engle, R . F. (1982). A utoregressive Conditional Heteroskedasticity with Estimates of the Variance of United Kingdom Infation, Econometrica, Vol 50, pp. 987-1007.

Engle, R. F . (1983). Estimates of the Variance of US Infation B ased up on the ARCH Model, J ournal of Money, Credit, and Banking, Vol 15, pp. 286-301.

Fountas, S., K aranasos, M. and Karanassou, M. (2000). A GARCH M odel of In‡ation and Inłation Uncertainty with Simultaneous Feedback, Department of Economics and Related Studies, University of York, Discussion Paper, 2000-24.

Friedman, M. (1977). Nobel Lecture: Inłation and U nemployment, J ournal of Political Economy, Vol 85, pp. 451-472.

Grier, K. and Perry, M. (1998). On In‡ation and In‡ation Uncertainty in the G7 Countries, J ournal of International M oney and Finance, Vol 17, pp. 671-689.

Grier, K. and Perry, M. (2000). The Exects of Real and Nominal Uncertainty on Infation and $\mathrm{O}$ utput Growth: Some GA RCH-M Evidence, J ournal of Applied E conometrics, Vol 15, pp. 45-58.

Grier, K . and Tullock, G. (1989). An E mpirical A nalysis of Cross-National Economic Growth, J ournal of M onetary E conomics, Vol 24, pp. 259-276.

Gros, D. and Thygesen, N. (1992). European Monetary Integration, Longman.

Holland, S. (1993). In¥ation Regimes and the Sources of In¥ation Uncertainty: a Comment, J ournal of M oney, Credit, and Banking, Vol 25, pp. 514-520.

Holland, S. (1995). Infation and Uncertainty: Test for Temporal Ordering, J ournal of M oney, Credit, and B anking, Vol 27, pp. 827-837.

J udson, R. and Orphanides, O. (1999). Inłation, Volatility, and Growth, International Finance, $\mathrm{Vol} 2$, pp. 117-138.

Nelson, D. B. (1991). Conditional Heteroskedasticity in Asset Returns: A New A pproach, Econometrica, Vol 59, pp. 347-370.

R ogox, K. (1985). The Optimal Degree of Commitment to an Intermediate Target, Quarterly J ournal of Economics, Vol 110, pp. 1169-89. 


\section{APPENDIX A}

This appendix reports the estimation results of an Exponential GARCH-in-mean model of in $¥$ ation in six countries with lagged in $\neq$ ation included in the conditional variance. A s in the text, the estimation period is 1960-1999 and the data frequency quarterly. We simultaneously estimate a system of equations that allows only the current value of either the conditional variance or standard deviation of in $\neq a t i o n^{18}$ to ax ect average in $\ddagger$ ation and also allows up to the twelfth lag of average infation to in $\neq$ uence the conditional variance. The model includes the in $¥$ ation equation which adds the in $¥$ ation variance to the equation reported in the text

$$
\pi_{t}=e_{t ; 1}+\delta h_{t}+\varepsilon_{t}
$$

with

$$
\varepsilon_{t}=e_{t} h_{t}^{\frac{1}{2}}
$$

and the conditional variance equation:

$$
\text { (1 i } \beta L) \ln \left(h_{t}\right)=\omega+c \mathbf{j} e_{t ; 1} \mathbf{j}+d e_{t \mathbf{i} 1}+k_{i} \pi_{t \mathbf{i}} i
$$

In the mean equation, $e_{t_{1}}$ stands for the part of the regression that includes the intercept and lagged infation rates. In the variance equation, various lags of in $\neq$ ation (from 1 to 12) were considered with the best model chosen on the basis of the minimum value of the

\begin{tabular}{|c|c|c|c|c|}
\hline & $\underset{\text { Level }}{\mathrm{EGARCH}}$ & 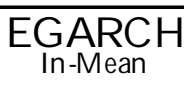 & \multicolumn{2}{|c|}{$\underset{\substack{\text { EGel } \\
\text { level }}}{\mathrm{EnRCH}}$} \\
\hline & $k_{i}$ & $\delta$ & $k_{i}$ & $\delta$ \\
\hline UK & $\begin{array}{r}k_{4}=23.67 \\
(0.03)\end{array}$ & $\begin{array}{l}17.28 \\
(0.32)\end{array}$ & $\begin{aligned} & k_{4}= 25.20 \\
&(0.03)\end{aligned}$ & $\begin{array}{l}7.92 \\
(0.72) \\
\end{array}$ \\
\hline FRANCE & $k_{6}=\begin{array}{l}6.26 \\
(0.00)\end{array}$ & $\begin{array}{c}177.18 \\
(0.00)\end{array}$ & $k_{4}=\frac{15.82}{(0.05)}$ & $\begin{array}{c}80.39 \\
(0.00)\end{array}$ \\
\hline GER MANY & $k_{4}=\frac{18.63}{(0.16)}$ & $\begin{array}{c}46.85 \\
(0.74)\end{array}$ & $k_{2}=\begin{array}{l}8.05 \\
(0.36)\end{array}$ & $\begin{array}{l}\begin{array}{l}46.21 \\
(0.65)\end{array} \\
\end{array}$ \\
\hline ITALY & $k_{4}=\begin{array}{l}8.42 \\
(0.06)\end{array}$ & i $\underset{(0.40)}{15.28}$ & $k_{6}=\begin{array}{r}3.40 \\
(0.08)\end{array}$ & i $\begin{array}{c}12.94 \\
(0.44)\end{array}$ \\
\hline NETH/NDS & $k_{6}=\begin{array}{l}3.21 \\
(0.76)\end{array}$ & $\begin{array}{l}2.50 \\
(0.79)\end{array}$ & $k_{12}=\underset{(0.97)}{0.37}$ & $\mathrm{i} \begin{array}{c}3.20 \\
(0.81)\end{array}$ \\
\hline SPAIN & $k_{6}=\underset{(0.04)}{20.74}$ & $\begin{array}{l}13.87 \\
(0.60)\end{array}$ & $k_{6}=\underset{(0.03)}{20.92}$ & $\mathrm{i} \begin{array}{c}3.99 \\
(0.60)\end{array}$ \\
\hline
\end{tabular}
A kaike information criterion.

The Table below reports only the estimated parameters of interest:

Notes: (1) Probability values are given in parentheses.

(2) $k_{i}$ indicates the estimated coec cient that corresponds to the ith lag in the in $¥$ ation rate.

$\mathrm{N}$ ote that when we estimate the model for the UK without the in-mean exect $(\delta=0)$, the coec cient for the exect of the 4th lag of in $\neq$ ation is 23.67 and is statistically signi ..cant.

\footnotetext{
${ }^{18} \mathrm{~A}$ ccording to the information criteria, the models with the variance of infation were preferred to those with the standard deviation.
} 
When we estimate the model without the level exect $\left(k_{i}=0\right)$, the in-mean coet cient is insigni..cant (the probability value is 0.32 ). When we estimate the model with the simultaneous feedback between the conditional variance and the conditional mean (last two columns in the Table), the above results imply a positive association between lagged infation and uncertainty similar to that found using the two-step method in the text. We do not ..nd a signi..cant exect of uncertainty on average in $\neq$ ation. However, as we emphasize in the text, such a result is plausible, as any relationship where uncertainty infuences average in ation takes time to materialize and cannot be fairly tested in a model that restricts the exect to being contemporaneous.

A comparison of the results of the simultaneous estimation (last two columns in Table) with the Granger causal ity results reported in thetext for the rest of the countries indicates that, in general, there is consistency between the two approaches. In particular, as far as the Friedman hypothesis (signi...cance of $k_{i}$ ) is concerned, we ..nd the two approaches to be in agreement, except in the case of the N etherlands. However, a comparison of the signi..cance of the causal exect of in ation uncertainty on the in $¥$ ation rate is not valid due to the contemporaneous nature of the exect under the simultaneous approach. As expected, the simultaneous approach does not detect such an exect in the majority of countries considered. 
Table 1:

(a) In ation unit root tests

\begin{tabular}{ccc}
\hline Country & AD F t-statistic & Phillips-Perron t-statistic \\
UK & $-2.620^{* * *}$ & $-8.040^{* * *}$ \\
\hline
\end{tabular}

Notes: (1) In the ADF tests, we use two lagged dixerenced terms. In the Phillips-Perron tests, the truncation lag is set at four.

(2) $* * *$ indicates rejection of the unit root null at the 0.01 level.

(b) The estimated AR(6)-EGARCH(1,1) Model for the UK infation rate

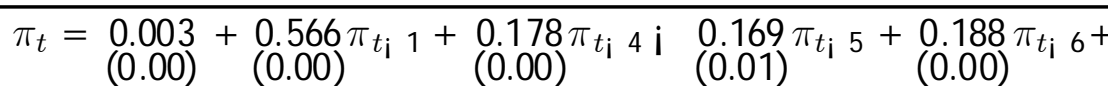

$$
\begin{aligned}
& +\underset{(0.00)}{0.009} d_{2 t} \text { i } \quad 0.007 d_{3 t}+\varepsilon_{t} \\
& \ln \left(\mathrm{h}_{t}\right)=\underset{(0.01)}{-3.196}+\underset{(0.00)}{0.697} \ln \left(\mathrm{h}_{t ;} 1\right)+\underset{(0.18)}{0.242} \mathrm{j} e_{t_{\mathrm{i}} 1 \mathrm{j}}+\underset{(0.02)}{0.437} e_{t_{\mathrm{i}} 1} \\
& \mathrm{Q}(12)=8.789[0.721], \mathrm{Q}(24)=24.810[0.416], \mathrm{Q}(36)=38.650[0.351] \\
& \mathrm{Q}^{2}(12)=12.957[0.372], \mathrm{Q}^{2}(24)=22.579[0.545], \mathrm{Q}^{2}(36)=26.794[0.867]
\end{aligned}
$$

Notes: (1) The ..rst equation represents the estimated conditional mean of the autoregressive

\begin{tabular}{|c|c|c|c|c|}
\hline & $\mathrm{H}_{0}: \pi_{t} ! h_{\pi t}$ & $\mathrm{H}_{0}: h_{\pi t} ! \pi_{t}$ & $\mathrm{H}_{0}: h_{\pi t} ! y_{t}$ & $\mathrm{H}_{0}^{a}: h_{\pi t} !$ \\
\hline Two Lags & $4.741^{\infty}(+)$ & $3.070^{\infty}(+)$ & $8.775^{\infty}(-)$ & $6.770^{\infty}(-)$ \\
\hline Four Lags & $4.721^{(+)}$ & $8.343^{x x}(-)$ & $6.410^{\infty}(-)$ & $3.589^{\infty}(-)$ \\
\hline Six Lags & $9.202^{(+)}$ & $6.864^{\infty}(+)$ & $5.410^{\infty 000}(-)$ & 1.610 \\
\hline Eight Lags & $5.294^{\infty}(+)$ & $5.568^{\not}(-)$ & $3.345^{x}(-)$ & 0.966 \\
\hline
\end{tabular}
model. $d_{2 t}$ and $d_{3 t}$ are seasonal dummies. The ..gures in parentheses under the coec cients and inside the square brackets show the probability values.

Table 2: Granger-Causality tests: UK (1960-1999)

Notes: (1) The ..gures are F statistics. (2) $\pi_{t} ! h_{\pi t}$ : Infation does not Granger-cause in ation uncertainty; $h_{\pi t}$ ! $\pi_{t}$ : I nłation uncertainty does not G ranger-cause in $\neq$ ation; $h_{\pi t}$ ! $y_{t}:$ In ation uncertainty does not Granger-cause output growth. (3) superscript (a) means that lagged in $\neq$ ation has been added to the regression. (4) the positive or negative sign in parentheses indicates the sign of the sum of the lagged coed cients in the respective equation. (5) $* * *, * *$ and $*$ indicate rejection of the null hypothesis at the $0.01,0.05$ and 0.10 levels of signi..cance, respectively. 
Table 3: Infation unit root tests

\begin{tabular}{ccc}
\hline Country & ADF t-statistic & Phillips-Perron t-statistic \\
& & \\
France & -1.910 & $-3.110^{* *}$ \\
Germany & -2.150 & $-5.420^{* * *}$ \\
I taly & -2.340 & $-3.880^{* * *}$ \\
Netherlands & $-4.840^{* * *}$ & $-11.150^{* * *}$ \\
Spain & $-2.720^{*}$ & $-6.550^{* * *}$ \\
\hline
\end{tabular}

Notes: (1) In the ADF tests we use two lagged dixerenced terms. In the Phillips-Perron tests the truncation lag is set at four, (2) $* * *, * *$ and $*$ indicate rejection of the unit root null at the $0.01,0.05$ and 0.10 level s of signi..cance, respectively.

Table 4: The Estimated AR(p)-EGARCH(1,1) Models

\begin{tabular}{cccccc}
\hline & \multicolumn{3}{c}{ Country } & \\
\cline { 2 - 6 } Parameter & France & Germany & I taly & Neth/nds & Spain \\
\hline$\pi_{t \mathrm{i}} 1$ & $0.645[0.000]$ & $0.351[0.000]$ & $0.754[0.000]$ & $0.471[0.000]$ & $0.182[0.006]$ \\
$\pi_{t \mathrm{i}} 2$ & $-0.016[0.837]$ & & $0.114[0.240]$ & & $0.247[0.001]$ \\
$\pi_{t \mathrm{i}} 3$ & $0.296[0.000]$ & $0.279[0.000]$ & $0.063[0.408]$ & & $0.191[0.022]$ \\
$\pi_{t \mathrm{i} 4}$ & & $0.361[0.000]$ & $0.039[0.420]$ & $0.337[0.000]$ & $0.232[0.000]$ \\
$\pi_{t \mathrm{i}} 5$ & & & & $-0.195[0.000]$ & \\
$\pi_{t \mathrm{i} 6}$ & & & & $0.115[0.010]$ & \\
$\pi_{t \mathrm{i}} 7$ & & $-0.205[0.003]$ & & & $-0.193[0.003]$ \\
$\pi_{t \mathrm{i}} 8$ & & & & $0.218[0.000]$ & $0.253[0.000]$ \\
$d$ & $0.223[0.000]$ & $-0.032[0.736]$ & $0.422[0.000]$ & $0.347[0.050]$ & $0.126[0.001]$ \\
$c$ & $-0.215[0.013]$ & $0.319[0.070]$ & $-0.194[0.000]$ & $0.912[0.000]$ & $-0.163[0.048]$ \\
$\beta$ & $0.942[0.000]$ & $0.680[0.011]$ & $0.942[0.000]$ & $0.745[0.000]$ & $0.969[0.000]$ \\
\hline
\end{tabular}

Notes: (1) The estimated conditional variance equation has the form:

$\ln \left(\mathrm{h}_{t}\right)=\omega+\beta \ln \left(\mathrm{h}_{t_{\mathrm{i}} 1}\right)+c \mathrm{j} e_{t \mathrm{i} 1} \mathrm{j}+d e_{t_{\mathrm{i}} 1}$

(2) A constant term and seasonal dummies were included but not reported.

(3) P robability values are given in square brackets. 
Table 5: Granger causality tests for inłation and inłation uncertainty (1960-1999)

\begin{tabular}{|c|c|c|c|c|}
\hline & $\mathrm{H}_{0}: \pi_{t} ! h_{\pi t}$ & $\mathrm{H}_{0}: h_{\pi t} ! \pi_{t}$ & $\mathrm{H}_{0}: h_{\pi t} ! y_{t}$ & $\mathrm{H}_{0}^{a}: h_{\pi t} !$ \\
\hline \multicolumn{5}{|l|}{ (A) France } \\
\hline T wo Lags & $46.381^{\infty}(+)$ & $6.319^{a x a}(+)$ & 0.274 & 1.425 \\
\hline Four Lags & $28.570^{\cos \alpha}(+)$ & 0.002 & 0.443 & 0.657 \\
\hline Six Lags & $22.838^{0000}(+)$ & 0.240 & 1.128 & $1.902^{\not \alpha}(+)$ \\
\hline Eight Lags & $17.676^{\infty}(+)$ & 0.918 & 1.003 & 1.110 \\
\hline \multicolumn{5}{|l|}{ (B) Germany } \\
\hline T wo Lags & 1.200 & 0.946 & 0.850 & 0.728 \\
\hline Four Lags & 0.669 & $2.780^{\infty x a}(-)$ & 0.517 & 0.528 \\
\hline Six Lags & 0.350 & $3.235^{\infty}(-)$ & 1.151 & 0.535 \\
\hline Eight Lags & 0.407 & $3.520^{a x p a}(-)$ & 0.803 & 0.409 \\
\hline \multicolumn{5}{|l|}{ (C) Italy } \\
\hline Two Lags & $42.552^{200 x}(+)$ & 0.039 & $2.540^{\alpha}(-)$ & 0.023 \\
\hline Four Lags & $39.568^{\infty}(+)$ & $4.5590(+)$ & 1.277 & 0.389 \\
\hline Six Lags & $34.108^{000 x}(+)$ & $6.458^{.000}(+)$ & 0.856 & 0.853 \\
\hline Eight Lags & $38.773^{0000}(+)$ & $4.334^{000}(+)$ & $1.754^{\mathrm{x}}(-)$ & 1.016 \\
\hline \multicolumn{5}{|c|}{ (D) The Neth/nds } \\
\hline T wo Lags & $20.394^{\infty}(+)$ & $5.188^{\infty}$ & $8.106^{\infty}(+)$ & $5.978(+)$ \\
\hline Four Lags & $9.382^{0000}(+)$ & $5.256^{\cos }(-)$ & $6.88900 x(+)$ & $3.318^{\mathrm{a}}(+)$ \\
\hline Six Lags & $10.114^{\infty}(+)$ & $3.526^{\infty}$ & $3.734^{\infty}(+)$ & $1.806^{\alpha}(+)$ \\
\hline Eight Lags & $8.280^{\infty}(+)$ & $2.820^{\operatorname{man}(-)}$ & $7.823^{\infty}(+)$ & 0.606 \\
\hline \multicolumn{5}{|l|}{ (E) Spain } \\
\hline T wo Lags & $10.021^{\infty}(+)$ & 1.081 & $3.254^{x x}(+)$ & $6.643^{\infty a x}(+)$ \\
\hline Four Lags & $8.221^{\infty}(+)$ & 0.454 & 1.766 & $3.256^{\infty}(+)$ \\
\hline Six Lags & $7.142^{\infty}(+)$ & $2.227^{\alpha \infty}(+)$ & $2.113^{\alpha x}(+)$ & $4.026^{2}(+)$ \\
\hline Eight Lags & $4.952^{\infty}(+)$ & $2.212^{\alpha \alpha}(+)$ & 1.346 & $3.677^{\infty}(+)$ \\
\hline
\end{tabular}

Notes: (1) The ..gures are $F$ statistics.

(2) $\pi_{t} ! h_{\pi t}$ : Inłation does not G ranger-cause infation uncertainty; $h_{\pi t} ! \pi_{t}$ : Inłation uncertainty does not Granger-cause inłation; $h_{\pi t}$ ! $y_{t}$ : In $\neq$ ation uncertainty does not Grangercause output growth.

(3) superscript (a) means that lagged infation has been added to the regression.

(4) the positive or negative sign in parentheses indicates the sign of the sum of the lagged coet cients in the respective equations.

(5) $* * *, * *$ and $*$ indicate rejection of the null at the $0.01,0.05$ and 0.10 levels of signi..cance, respectively. 
Table 6: Granger-Causality tests: UK

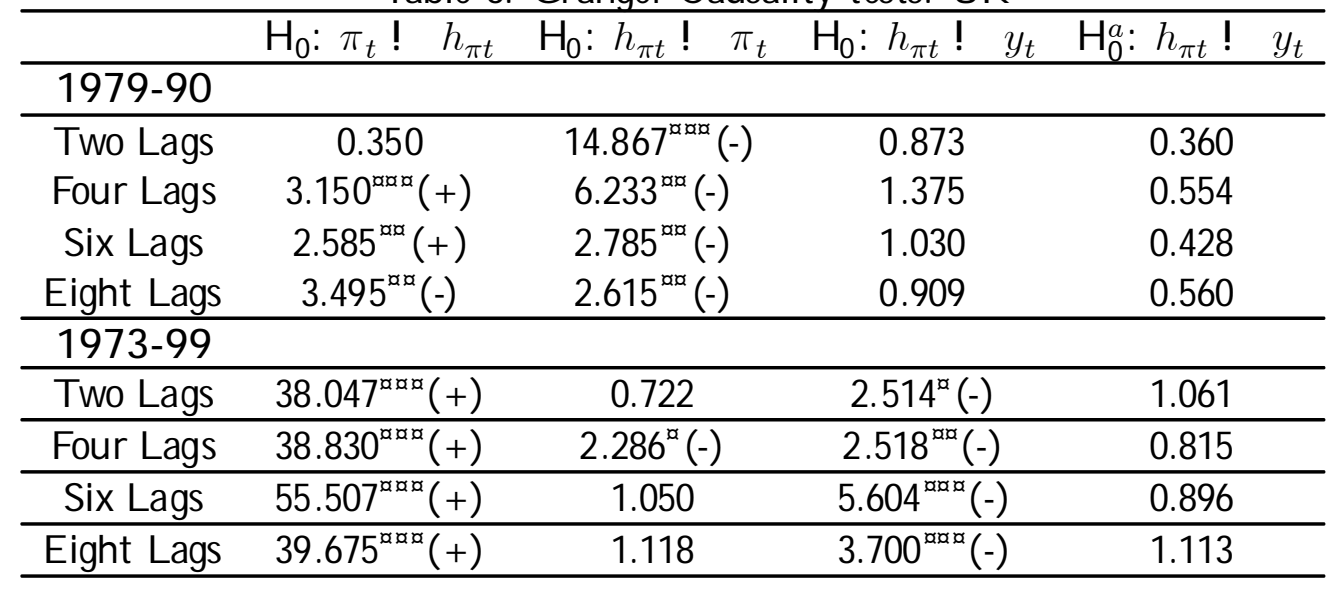

Notes: (1) The ..gures are F statistics.

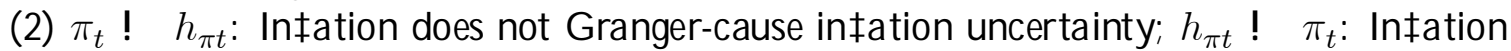
uncertainty does not Granger-cause in $\ddagger$ ation; $h_{\pi t} ! y_{t}$ : In $\neq$ ation uncertainty does not Grangercause output growth.

(3) superscript (a) means that lagged in $\ddagger$ ation has been added to the regression.

(4) the positive or negative sign in parentheses indicates the sign of the sum of the lagged coed cients in the respective equations.

(5) $* * *, * *$ and $*$ indicate rejection of the null at the $0.01,0.05$ and 0.10 levels of signi..cance, respectively. 
Table 7: Granger causality tests for inłation and inłation uncertainty (1983-1999)

\begin{tabular}{|c|c|c|c|c|}
\hline & $\mathrm{H}_{0}: \pi_{t} ! h_{\pi t}$ & $\mathrm{H}_{0}: h_{\pi t} ! \pi_{t}$ & $\mathrm{H}_{0}: h_{\pi t} ! y_{t}$ & $\mathrm{H}_{0}^{a}: h_{\pi t} ! y_{t}$ \\
\hline \multicolumn{5}{|l|}{ (A) France } \\
\hline T wo Lags & $4.724^{a x}(+)$ & 0.001 & 2.015 & $2.373^{\alpha}(+)$ \\
\hline Four Lags & $3.432^{\alpha \infty}(+)$ & 0.169 & 1.905 & 1.766 \\
\hline Six Lags & $3.031^{a x}(+)$ & 0.237 & 0.552 & 1.018 \\
\hline Eight Lags & $3.111^{\infty}(+)$ & 0.396 & 0.604 & 1.269 \\
\hline \multicolumn{5}{|l|}{ (B) G ermany } \\
\hline T wo Lags & $2.762^{\alpha}(+)$ & 0.651 & 1.566 & 1.410 \\
\hline Four Lags & $4.026^{.000}(+)$ & 0.943 & 1.670 & 1.689 \\
\hline Six Lags & $2.927^{\infty x}(+)$ & 0.845 & $2.479^{\infty \alpha}(-)$ & 1.643 \\
\hline Eight Lags & $2.293^{x}(+)$ & 0.691 & $1.937^{\propto}(-)$ & 1.374 \\
\hline \multicolumn{5}{|l|}{ (C) I taly } \\
\hline T wo Lags & $5.898^{\infty}(+)$ & $3.605^{0 x \alpha}(-)$ & 1.127 & 2.079 \\
\hline Four Lags & $5.576^{\infty}(+)$ & $2.038^{\ltimes}(-)$ & 0.780 & 1.535 \\
\hline Six Lags & $3.015^{a x}(+)$ & $2.933^{\infty x}(-)$ & 1.018 & 1.778 \\
\hline Eight Lags & $1.947^{\alpha}(+)$ & $2.608^{\infty x}(-)$ & 1.033 & 0.844 \\
\hline \multicolumn{5}{|c|}{ (D) The Neth/nds } \\
\hline T wo Lags & $3.829^{a x}(-)$ & $4.492^{\infty x}(-)$ & 0.546 & 0.299 \\
\hline Four Lags & $8.285^{0000}(-)$ & 1.442 & $2.068^{\alpha}(+)$ & 0.124 \\
\hline Six Lags & $14.995^{2}(-)$ & 0.971 & 1.585 & 0.297 \\
\hline Eight Lags & $9.717^{\cos x}(-)$ & 1.069 & 0.539 & 0.686 \\
\hline \multicolumn{5}{|l|}{ (E) Spain } \\
\hline Two Lags & 0.890 & 1.629 & 0.081 & 0.074 \\
\hline Four Lags & 1.567 & 1.659 & $2.594^{a x}(+)$ & $2.923^{100}(+)$ \\
\hline Six Lags & 0.754 & 1.483 & $2.004^{a}(+)$ & 1.549 \\
\hline Eight Lags & 0.561 & 1.772 & 1.626 & 1.245 \\
\hline
\end{tabular}

Notes: (1) The ..gures are F statistics.

(2) $\pi_{t} ! h_{\pi t}:$ Infation does not $\mathrm{G}$ ranger-cause infation uncertainty; $h_{\pi t} ! \pi_{t}:$ In $\ddagger$ ation uncertainty does not Granger-cause in $\neq$ ation; $h_{\pi t}$ ! $y_{t}$ : In $\neq$ ation uncertainty does not Grangercause output growth.

(3) superscript (a) means that lagged in $\ddagger$ ation has been added to the regression.

(4) the positive or negative sign in parentheses indicates the sign of the sum of the lagged coec cients in the respective equations.

(5) ***,** and * indicate rejection of the null at the $0.01,0.05$ and 0.10 levels of signi..cance, respectively. 

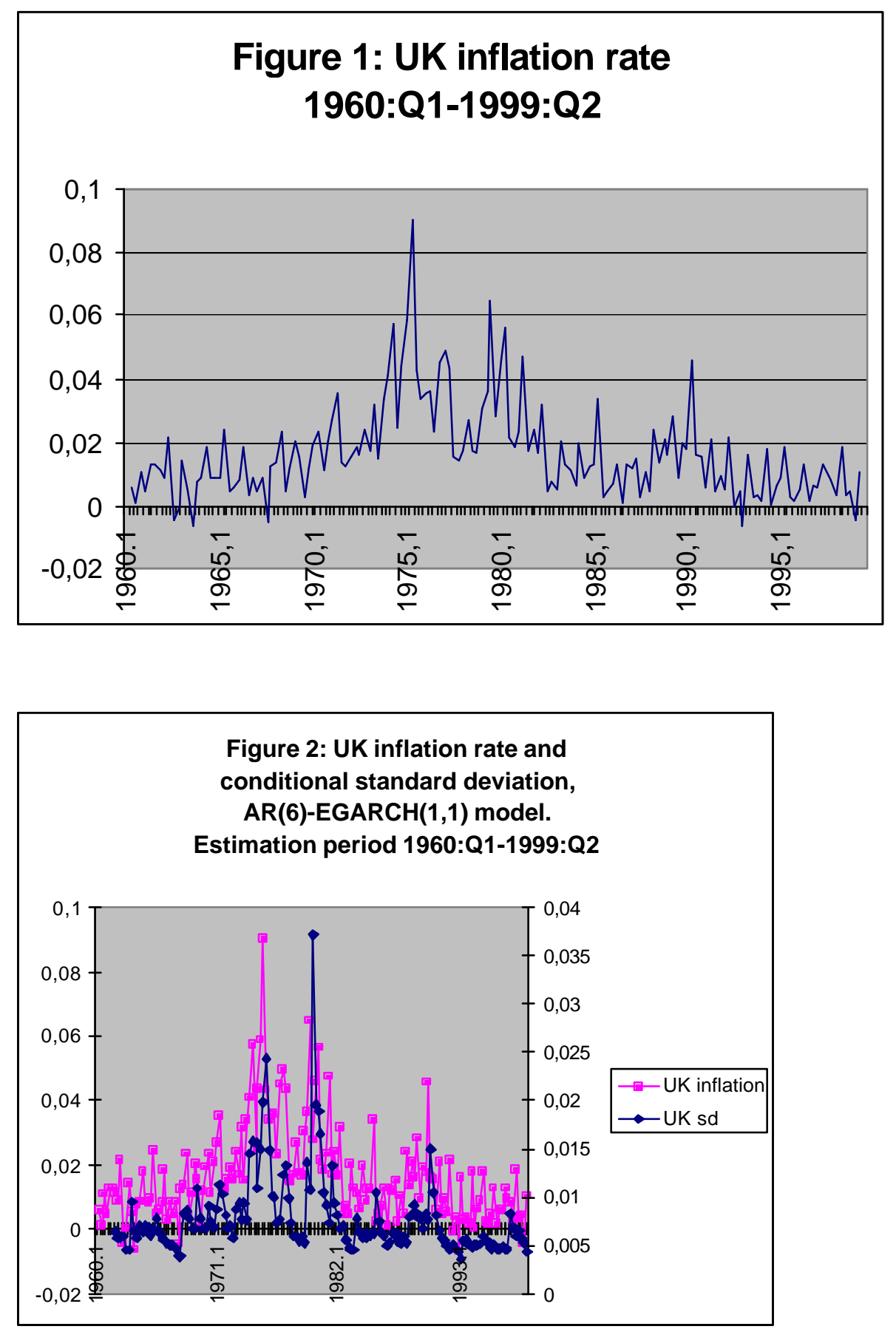


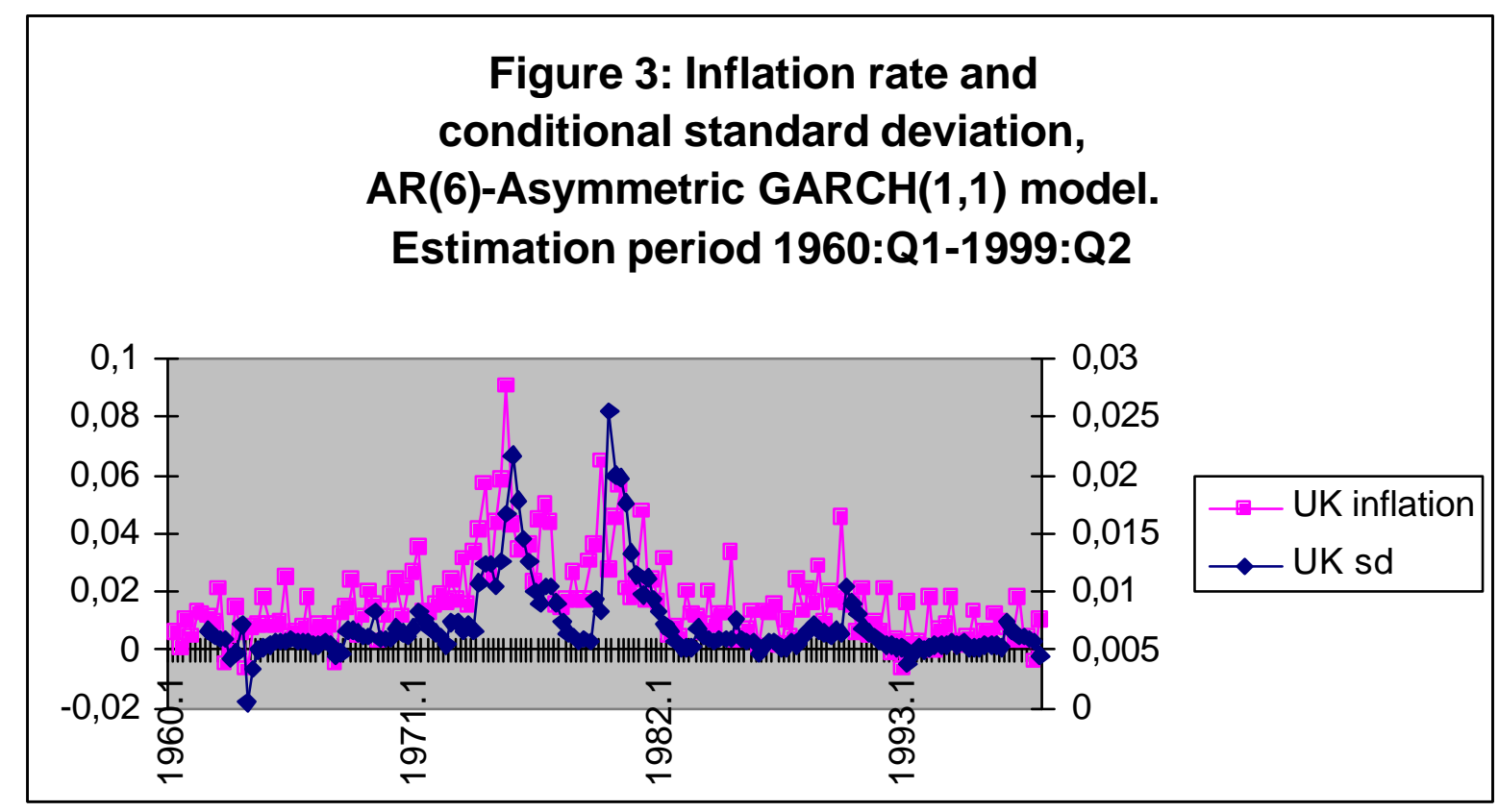

